\title{
Comparative Study on
} Performance Stability of Ni-Oxide Cermet Anodes under Humidified Atmospheres in Solid Oxide Fuel Cells

\section{$\operatorname{AUTHOR}(\mathrm{S})$ :}

Matsui, Toshiaki; Kishida, Ryo; Muroyama, Hiroki; Eguchi, Koichi

\section{CITATION:}

Matsui, Toshiaki ...[et al]. Comparative Study on Performance Stability of Ni-Oxide Cermet Anodes under Humidified Atmospheres in Solid Oxide Fuel Cells. Journal of The Electrochemical Society 2012, 159(8): F456-F460

ISSUE DATE:

2012-07-20

URL:

http://hdl.handle.net/2433/193701

\section{RIGHT:}

(C) The Electrochemical Society, Inc. 2012. All rights reserved. Except as provided under U.S. copyright law, this work may not be reproduced, resold, distributed, or modified without the express permission of The Electrochemical Society (ECS). 


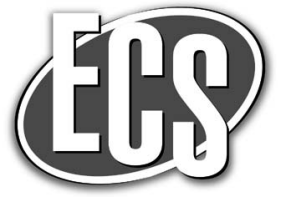

\title{
Comparative Study on Performance Stability of Ni-Oxide Cermet Anodes under Humidified Atmospheres in Solid Oxide Fuel Cells
}

\author{
Toshiaki Matsui,,"z Ryo Kishida, Hiroki Muroyama," and Koichi Eguchi* \\ Department of Energy and Hydrocarbon Chemistry, Graduate School of Engineering, Kyoto University, Nishikyo-ku, \\ Kyoto 615-8510, Japan
}

\begin{abstract}
The influence of the oxide component in $\mathrm{Ni}$-oxide based cermet anodes on the performance stability was examined at $1000^{\circ} \mathrm{C}$ with a supply of highly humidified hydrogen, $40 \% \mathrm{H}_{2} \mathrm{O}-60 \% \mathrm{H}_{2}$. Three types of anodes were applied; Ni-samaria-doped ceria (Ni-SDC), $\mathrm{Ni}$-yttria-stabilized zirconia (Ni-YSZ), and Ni-scandia-stabilized zirconia (Ni-ScSZ). Abrupt deterioration in performance was confirmed during constant current operation for the cells with Ni-YSZ and Ni-ScSZ anodes, accompanied with a drastic increase in ohmic resistance between the anode and reference electrode. In contrast, the performance of cell with Ni-SDC anode was pretty stable for $48 \mathrm{~h}$. These differences in performance stability were significantly related to the local partial pressure of steam in the vicinity of the electrochemically active sites because the surface oxidation of nickel particles resulted in the deterioration. The microstructural changes in Ni-YSZ and Ni-SDC anodes upon discharge were also quantified by the dual-beam focused ion beam-scanning electron microscopy (FIB-SEM). The electrochemical behavior observed in each anode had a strong correlation with the anode microstructure such as triple phase boundary length and nickel particle size.
\end{abstract}

(C) 2012 The Electrochemical Society. [DOI: 10.1149/2.053208jes] All rights reserved.

Manuscript submitted March 2, 2012; revised manuscript received May 22, 2012. Published July $20,2012$.

Solid oxide fuel cells (SOFCs) are promising energy conversion systems for the next generation, e.g., the residential SOFC cogeneration system has been commercially supplied in Japan. However, still many technological issues should be settled to assure the durability and reliability of SOFC stack/system prior to wide spread commercialization. The extraction of degrading factors under various operating conditions is indispensable to elucidate the degradation mechanisms and feeds the knowledge back to the development and manufacturing processes.

The porous cermets consisting of nickel and oxide ceramics (abbreviated as $\mathrm{Ni-oxide)} \mathrm{are} \mathrm{widely} \mathrm{used} \mathrm{as} \mathrm{anode} \mathrm{materials} \mathrm{in} \mathrm{SOFCs:}$ Ionic conductors or mixed ionic-electronic conductors are applicable for the oxide ceramics. In these cermets, the electrochemical reaction takes place at the triple phase boundary (TPB) of reactant gas/electronic conductor/ionic conductor. Therefore, the microstructure of cermet anodes has a significant impact on performance as well as stability upon the prolonged operation, and the quantification of microstructural change provides the essential information for the understanding of degradation mechanisms. For example, recently, we have reported the correlation between the performance and microstructural change of $\mathrm{Ni}-\left(\mathrm{Sc}_{2} \mathrm{O}_{3}\right)_{0.10}\left(\mathrm{CeO}_{2}\right)_{0.01}\left(\mathrm{ZrO}_{2}\right)_{0.89}$ anode in the cathodesupported tubular cells subjected to long term operation. ${ }^{1,2}$ The nickel particles were excluded significantly from the anode/electrolyte interface to $4 \mu \mathrm{m}$-thick range after $6500 \mathrm{~h}$ of the operation, resulting in the significant reduction in performance and TPB length. It is thus of importance to evaluate the microstructural change in nickel particles during discharge.

The cell operation at high fuel utilizations is desirable to achieve the high efficiency, but the cermet anode in the downstream region is exposed to the lean fuel and high steam concentrations. Even under steady operation, the progresses of agglomeration and/or oxidation of nickel particles are inevitable during a long-term operation. ${ }^{3-7}$ In the previous report, the condition at the downstream part of the cell was simulated by feeding highly humidified hydrogen, and the resultant microstructural change of the Ni-YSZ anode upon discharge was quantified through the direct observation by the dual-beam focused ion beam-scanning electron microscopy (FIB-SEM) ${ }^{8}$ The terminal voltage of the cell suddenly deteriorated upon the galvanostatic operation of $300 \mathrm{~mA} \mathrm{~cm}^{-2}$ at $1000^{\circ} \mathrm{C}$. In response to this behavior, nickel particles with rounded and smooth surface were changed to rough surface, while those exposed to the fuel under the open-circuit condition were unchanged. The TPB length of the degraded anode was evaluated to be two-thirds of the as-prepared anode. Therefore, the electrochemically generated steam was considered to be the main degradation

${ }^{*}$ Electrochemical Society Active Member.

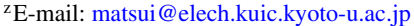

factor for this phenomenon. However, it is unclear whether a series of these phenomena is characteristic of Ni-YSZ anode or common to other Ni-oxide cermets. In this study, then, the influence of the oxide component in $\mathrm{Ni}$-oxide based cermet anodes on the performance stability was investigated under a highly humidified atmosphere. The correlation between the performance deterioration and microstructural change of $\mathrm{Ni}$-oxide anodes was evaluated quantitatively by FIB-SEM. As the oxide components, samaria-doped ceria, yttria-stabilized zirconia, and scandia-stabilized zirconia were applied, and the obtained results were compared to each other.

\section{Experimental}

Three different $\mathrm{Ni}$-oxide cermet anodes (Ni:oxide $=50: 50 \mathrm{vol} \%$ ) were fabricated by the mechanical mixing of $\mathrm{NiO}$ (Wako Pure Chemical Industries) and corresponding oxide powder. For the oxide component in the cermet, $8 \mathrm{~mol} \% \mathrm{Y}_{2} \mathrm{O}_{3}$-stabilized zirconia (Tosoh, abbreviated as YSZ), $10 \mathrm{~mol} \% \mathrm{Sc}_{2} \mathrm{O}_{3}$-stabilized zirconia (Daiichi Kigenso Kagaku Kogyo, ScSZ), and $10 \mathrm{~mol}_{\%} \mathrm{Sm}_{2} \mathrm{O}_{3}$-doped ceria (SDC) were used. The doped ceria was synthesized via the oxalate coprecipitation method. ${ }^{9}$ The mixtures of NiO-YSZ and NiO-ScSZ were heat-treated for $5 \mathrm{~h}$ at $1200^{\circ} \mathrm{C}$ and $1400^{\circ} \mathrm{C}$, respectively, while the NiO-SDC mixture was used without any pretreatment. The resultant powders were mixed with polyethylene glycol (Wako Pure Chemical Industries) to form slurry.

A disk of YSZ (Tosoh, $24 \mathrm{~mm}$ in diameter, $500 \mu \mathrm{m}$ in thickness) was applied as an electrolyte for the electrolyte-supported cells. The slurries of NiO-YSZ and $\mathrm{NiO}-\mathrm{ScSZ}$ was screen-printed onto the electrolyte and subsequently fired at $1400^{\circ} \mathrm{C}$ for $5 \mathrm{~h}$ in air. In the case of NiO-SDC slurry, the firing temperature was lowered to $1280^{\circ} \mathrm{C}$ to prevent the chemical reaction between YSZ and SDC. Lanthanum strontium manganite, $\left(\mathrm{La}_{0.8} \mathrm{Sr}_{0.2}\right)_{0.97} \mathrm{MnO}_{3}$ (abbreviated as LSM), was used as a cathode material, which was prepared from corresponding metal acetates. Reagents in the required molar ratio were dissolved in water, and then dried at $120^{\circ} \mathrm{C}$. Resulting powder was milled for $24 \mathrm{~h}$ and calcined at $900^{\circ} \mathrm{C}$ for $5 \mathrm{~h}$. The other surface of the YSZ disk was screen-printed with LSM slurry, and subsequently fired at $1150^{\circ} \mathrm{C}$ for $5 \mathrm{~h}$ in air. A platinum reference electrode was attached so as to surround the side edge of the thin disk. The area of anode and cathode was $0.28 \mathrm{~cm}^{2}$ with a symmetrical configuration. The single cell was sandwiched by alumina tubes with Pyrex glass seal as shown in Fig. 1.

Prior to the electrochemical measurements, NiO-oxide was reduced under a hydrogen atmosphere at $1000^{\circ} \mathrm{C}$. Then, the power generation was conducted at the terminal voltage of $0.8 \mathrm{~V}$ to stabilize the initial performance by feeding $\mathrm{H}_{2}-\mathrm{H}_{2} \mathrm{O}$ to the anode and $\mathrm{O}_{2}$ to 


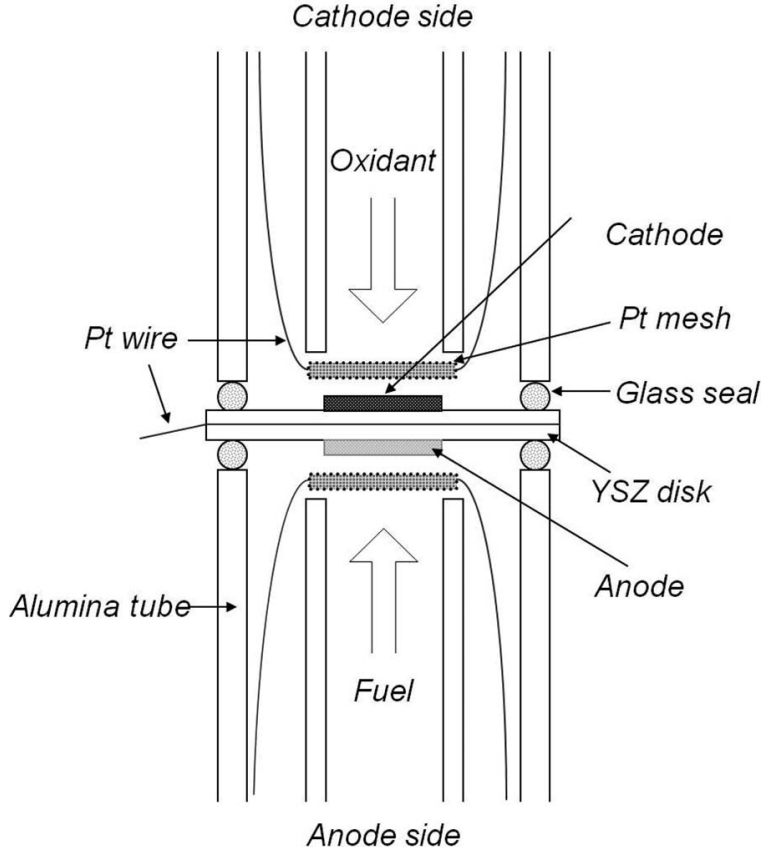

Figure 1. Schematic diagram of a cell configuration.

the cathode. Gaseous mixtures of $\mathrm{H}_{2}-\mathrm{H}_{2} \mathrm{O}, \mathrm{CO}-\mathrm{H}_{2} \mathrm{O}, \mathrm{H}_{2}-\mathrm{CO}_{2}$ and $\mathrm{CO}-\mathrm{CO}_{2}$ were supplied to the anode with a total flow rate of $100 \mathrm{~mL}$ $\min ^{-1}$. The $\mathrm{H}_{2}-\mathrm{H}_{2} \mathrm{O}$ and $\mathrm{CO}-\mathrm{H}_{2} \mathrm{O}$ mixed gases were prepared by bubbling hydrogen and carbon monoxide through water which was kept at various temperatures. Oxygen was supplied to the cathode with a flow rate of $100 \mathrm{~mL} \mathrm{~min}^{-1}$. Electrochemical measurements were conducted at $1000^{\circ} \mathrm{C}$ using the CellTest system (Solartron Analytical, $\mathrm{UK}$, potentiostat/galvanostat $1470 \mathrm{E}$ and frequency response analyzer 1455). AC Impedance spectra were measured at the open circuit state before and after discharge operation; the applied frequency was in the range of $0.1 \mathrm{~Hz}-1 \mathrm{MHz}$ with voltage amplitude of $10 \mathrm{mV}$. In some cases, impedance spectra were also recorded in the frequency range of $1 \mathrm{kHz}-1 \mathrm{MHz}$ with the ac-amplitude of $5 \mathrm{~mA} \mathrm{~cm}^{-2}$ during discharge operation at $300 \mathrm{~mA} \mathrm{~cm}^{-2}$ in order to evaluate the ohmic resistance between anode and reference electrode.

Electrode microstructure observation was carried out using a dualbeam focused ion beam-scanning electron microscope (FIB-SEM, Nvision 40, Carl Zeiss-SIINT) equipped with an energy dispersive $\mathrm{X}$-ray spectrometer (EDX, Oxford). For the three-dimensional (3D) reconstruction of anode, the cell was infiltrated with epoxy resin (Marumoto Struers KK) under vacuum conditions, and then cut and polished. The $2 \mathrm{D}$ cross-sectional backscattered electron images $(x-y$ plane) of Ni-SDC anode were collected along the $z$-direction with a spacing of about $60 \mathrm{~nm}$ by sequential milling-and-observation operation. A more detailed description of analysis using a FIB-SEM is given in Iwai et al. ${ }^{10}$ The data sets of as-prepared and degraded $\mathrm{Ni}-$ YSZ were referred from the literatures, ${ }^{8,10}$ of which preparation procedure is the same as in this study. The $3 \mathrm{D}$ microstructure of $\mathrm{Ni}-$ oxide cermet anodes was virtually reconstructed in a computational field by aligning uniformly spaced cross-sectional SEM images. The volume fraction of each phase was directly calculated from the $3 \mathrm{D}$ data. The volume specific TPB length was calculated by the volume expansion method. In addition, the particle diameter of each phase was calculated by the line intercept method.

\section{Results and Discussion}

The influence of oxide species in the Ni-oxide cermet anodes on the performance stability was studied under a highly humidified atmosphere. Power generation tests were conducted with a constant current of $300 \mathrm{~mA} \mathrm{~cm}^{-2}$ in $40 \% \mathrm{H}_{2} \mathrm{O}-60 \% \mathrm{H}_{2}$ at $1000^{\circ} \mathrm{C}$. Figure 2 shows the time courses of (a) the terminal voltage, (b) ohmic resistance between
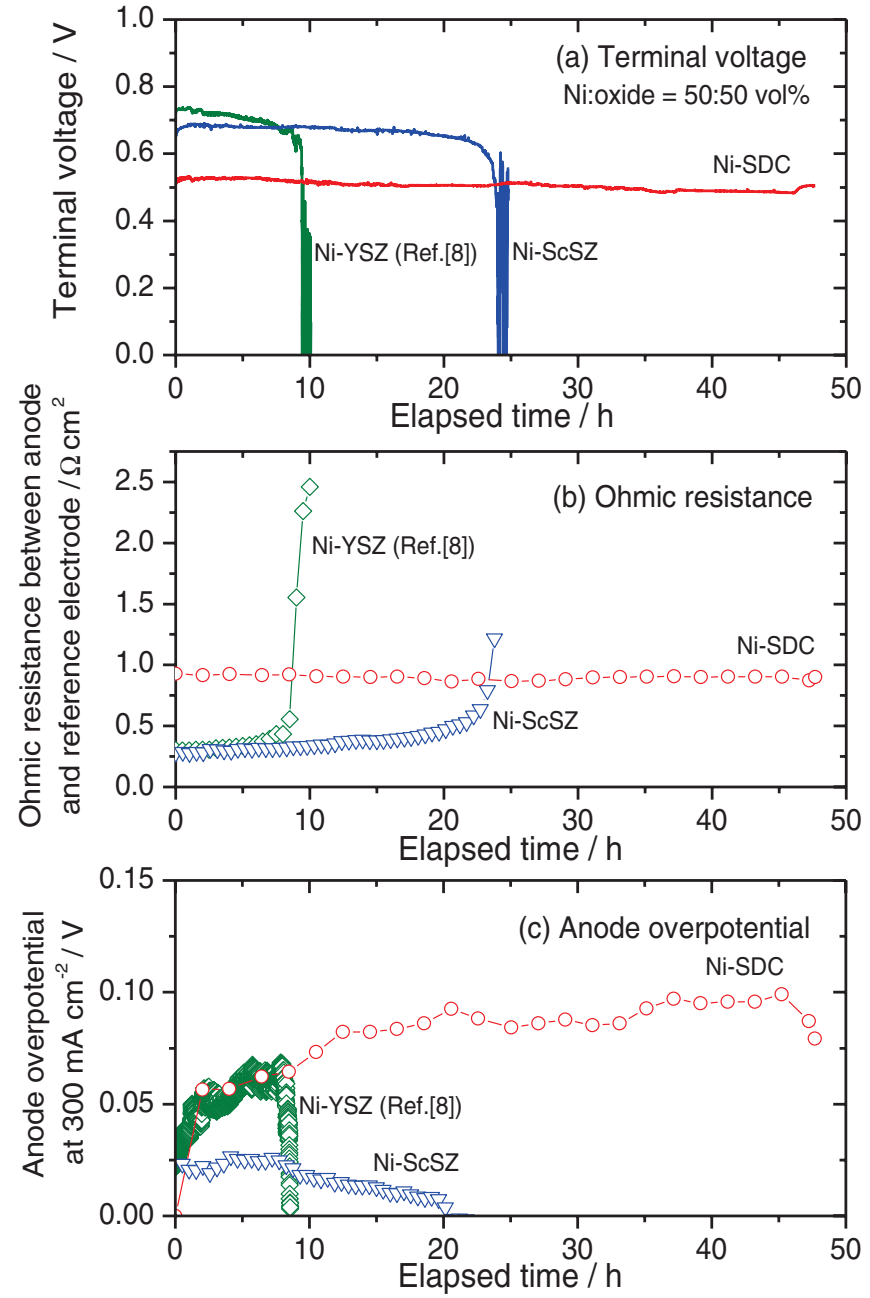

Figure 2. Time courses of (a) the terminal voltage for a single cell, (b) ohmic resistance between the anode and reference electrode, and (c) anode overpotential during discharge at $300 \mathrm{~mA} \mathrm{~cm}^{-2}$. Operating temperature: $1000^{\circ} \mathrm{C}$; Anode gas: $40 \% \mathrm{H}_{2} \mathrm{O}-60 \% \mathrm{H}_{2}$; Anodes: Ni-YSZ (Ref. 8), Ni-ScSZ, and Ni-SDC $($ Ni:oxide $=50: 50$ vol $\%$.

the anode and reference electrode, and (c) anode overpotential. The results for Ni-YSZ anode were referred from our previous paper. ${ }^{8}$ The gradual decrease and subsequent abrupt drop in terminal voltage were observed within $25 \mathrm{~h}$ for $\mathrm{Ni}-\mathrm{ScSZ}$ anode as in the case of Ni-YSZ, of which performance was deteriorated within $10 \mathrm{~h}$. A concomitant increase in ohmic resistance was also confirmed, whereas the anode overpotential was less than $25 \mathrm{mV}$ during discharge. In contrast, the cell employing Ni-SDC anode was stably discharged for $48 \mathrm{~h}$ without any change in ohmic resistance regardless of the low initial performance. This low performance is mainly due to the low firing temperature of Ni-SDC anode on YSZ electrolyte. In the previous study, we have suggested that the abrupt performance deterioration of the cell with Ni-YSZ anode is induced by a drastic increase in ohmic resistance rather than an increase in anode overpotential; the maximal anode overpotential was ca. $65 \mathrm{mV}$ (Fig. 2c). Impedance spectra of Ni-YSZ anode under the open-circuit condition before and after discharge are depicted in Fig. 3a. Although ohmic and polarization resistances increased significantly soon after the cutoff of passed current $(0 \mathrm{~min})$, both resistive components were partially recovered with time (15 and $30 \mathrm{~min}$ ) during the subsequent open-circuit state holding. Even under the discharge state, it was confirmed that the partial pressure of oxygen $\left(P\left(\mathrm{O}_{2}\right)\right)$ at the anode/electrolyte interface did not reach the ideal value of $\mathrm{NiO}$ formation by considering the gas diffusion process in the porous anode and the thermodynamic equi- 

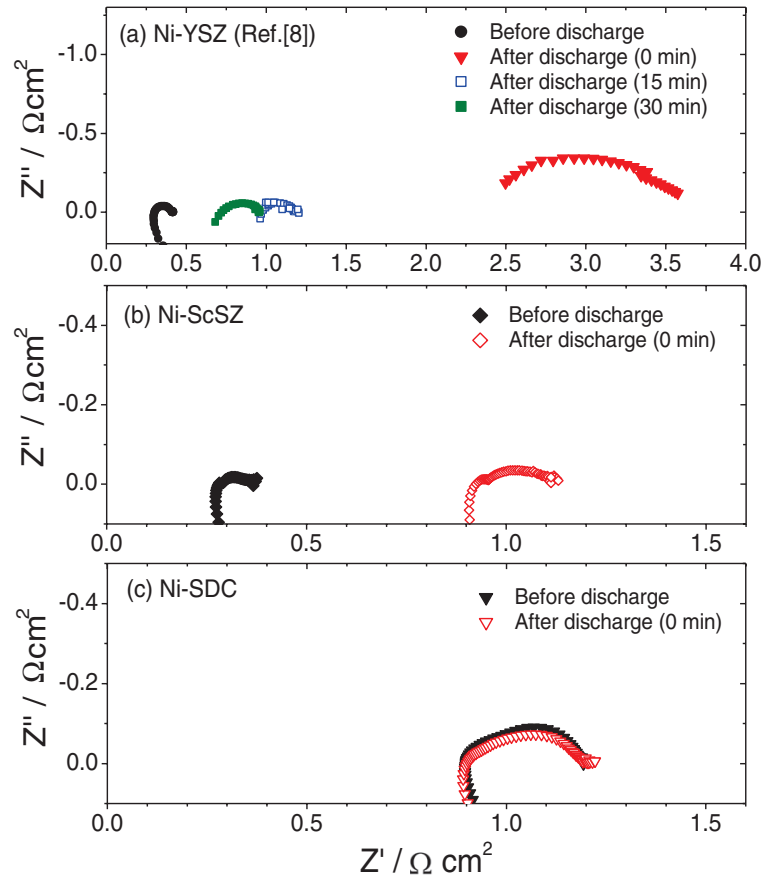

Figure 3. Impedance spectra of anodes under the open-circuit condition before and after discharge. Operating temperature: $1000^{\circ} \mathrm{C}$; Anode gas: $40 \% \mathrm{H}_{2} \mathrm{O}$ $60 \% \mathrm{H}_{2}$; Anode: (a) Ni-YSZ, (b) Ni-ScSZ, and (c) Ni-SDC.

librium. Thus, the surface oxidation of nickel particles, such as the formation of steam or hydroxide layer, resulted in interruption of the electronic conduction path. This finding was supported by the time course of terminal voltage in Fig. 4 for the cell with Ni-YSZ anode at a constant current of $300 \mathrm{~mA} \mathrm{~cm} \mathrm{~cm}^{-2}$ under the $P\left(\mathrm{O}_{2}\right)$ of 1.2 $\times 10^{-15} \mathrm{~atm}$. The gas composition in anode chamber was controlled to be the same $P\left(\mathrm{O}_{2}\right)$ in $40 \%$ humidified hydrogen. The slight difference in initial performance is due to the difference in the reactivity of gaseous species and the piece-to-piece variations of cells. Note that in the $\mathrm{CO}-\mathrm{H}_{2} \mathrm{O}$ atmosphere the terminal voltage was abruptly deteriorated, while the performance was stable over $45 \mathrm{~h}$ in $\mathrm{CO}-\mathrm{CO}_{2}$ and

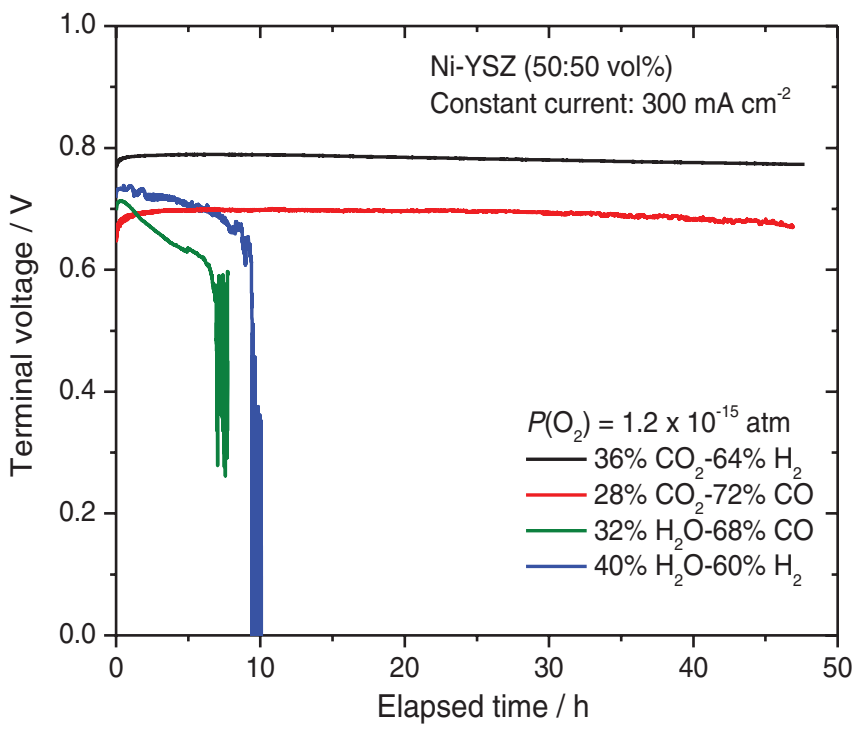

Figure 4. Time course of terminal voltage for a single cell with Ni-YSZ anode during discharge at $300 \mathrm{~mA} \mathrm{~cm}{ }^{-2} \cdot P\left(\mathrm{O}_{2}\right)$ in the fuel gas was controlled to be $1.2 \times 10^{-15} \mathrm{~atm}$. Operating temperature: $1000^{\circ} \mathrm{C}$.
$\mathrm{H}_{2}-\mathrm{CO}_{2}$ atmospheres. This result indicates that the steam serves as a deterioration factor in highly humidified atmospheres. Therefore, the deterioration observed for $\mathrm{Ni}-\mathrm{ScSZ}$ anode in Fig. 2 should be also induced by the same factor. In contrast, the stable power generation of Ni-SDC anode under a highly humidified atmosphere in Fig. 2 suggests the suppression of surface oxidation of nickel; as can be seen in Fig. 3, no change in impedance spectra was observed for NiSDC anode even after discharge, whereas for $\mathrm{Ni}-\mathrm{ScSZ}$ and $\mathrm{Ni}-\mathrm{YSZ}$ anodes both ohmic and polarization resistances increased. Since the discharge tests were conducted under the galvanostatic condition of $300 \mathrm{~mA} \mathrm{~cm} \mathrm{~cm}^{-2}$ in Fig. 2, the amount of electrochemically generated steam must be the same regardless of anode materials. Thus, the difference in the local partial pressure of steam $\left.\left(\mathrm{P}_{(\mathrm{H}} \mathrm{O}\right)\right)$ in the vicinity of electrochemically active sites is the critical factor, in determining the long-term stability. It is well recognized that the application of $\mathrm{Ni}$-ceria-based oxide cermet leads to the expansion of electrochemically active area from the TPB line, which is related to the preferable bulk properties of ceria such as ionic conductivity, electronic conductivity and solubility of proton, and the surface catalytic activity of ceria such as $\mathrm{H}_{2}$ and/or $\mathrm{H}_{2} \mathrm{O}$ adsorption, surface oxygen exchange, and reactivity with $\mathrm{H}_{2}$ and $\mathrm{H}_{2} \mathrm{O} .{ }^{11,12}$ The mixed conduction of ceriabased oxide induced by the partial reduction of $\mathrm{Ce}^{4+}$ to $\mathrm{Ce}^{3+}$ under reducing atmospheres provides the additional electronic conduction path and also contributes to increase the number of electrochemically active sites. In the case of Ni-SDC anode, therefore, these two factors effectively suppressed the local enrichment of $P\left(\mathrm{H}_{2} \mathrm{O}\right)$ in the vicinity of active zone, resulting in the stable discharge behavior.

The influence of the partial pressure of steam on the electrocatalytic activity was studied to clarify the affinity for steam in each cermet anode. Figure 5 shows the interfacial conductivity of the Nioxide cermet anodes as a function of $P\left(\mathrm{O}_{2}\right)$ and $P\left(\mathrm{H}_{2} \mathrm{O}\right)$ in the binary $\mathrm{H}_{2}-\mathrm{H}_{2} \mathrm{O}$ system under the open-circuit condition. The interfacial conductivity was calculated as the inverse of the polarization resistance as the impedance spectra consisted of only one semicircle. For Ni-YSZ anode, the conductivity increased with rises in $P\left(\mathrm{O}_{2}\right)$ and $P\left(\mathrm{H}_{2} \mathrm{O}\right)$; then, a local maximum was formed in the humidified range of $15-25 \% .^{8}$ Analogous tendency has been confirmed in Ni-ScSZ anode. ${ }^{13}$ This promotion effect of steam in the low humidity region

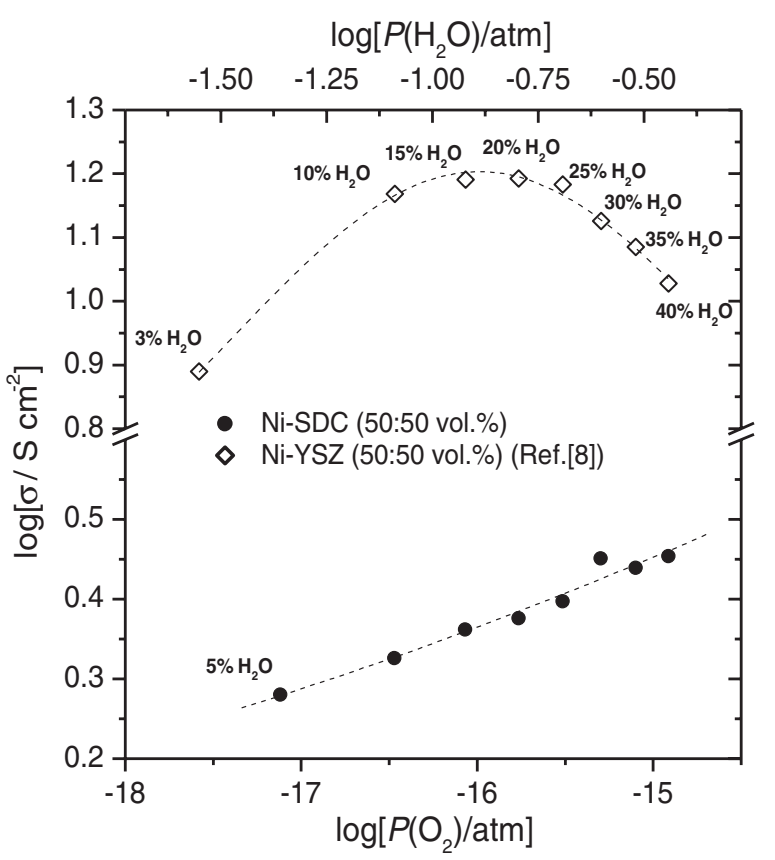

Figure 5. Interfacial conductivity of $\mathrm{Ni}-\mathrm{YSZ}$ and $\mathrm{Ni}-\mathrm{SDC}$ cermet anodes as functions of $P\left(\mathrm{O}_{2}\right)$ and $P\left(\mathrm{H}_{2} \mathrm{O}\right)$ at $1000^{\circ} \mathrm{C}$ under the open-circuit condition. Anode gas: $x \% \mathrm{H}_{2} \mathrm{O}-(100-x) \% \mathrm{H}_{2}$. 


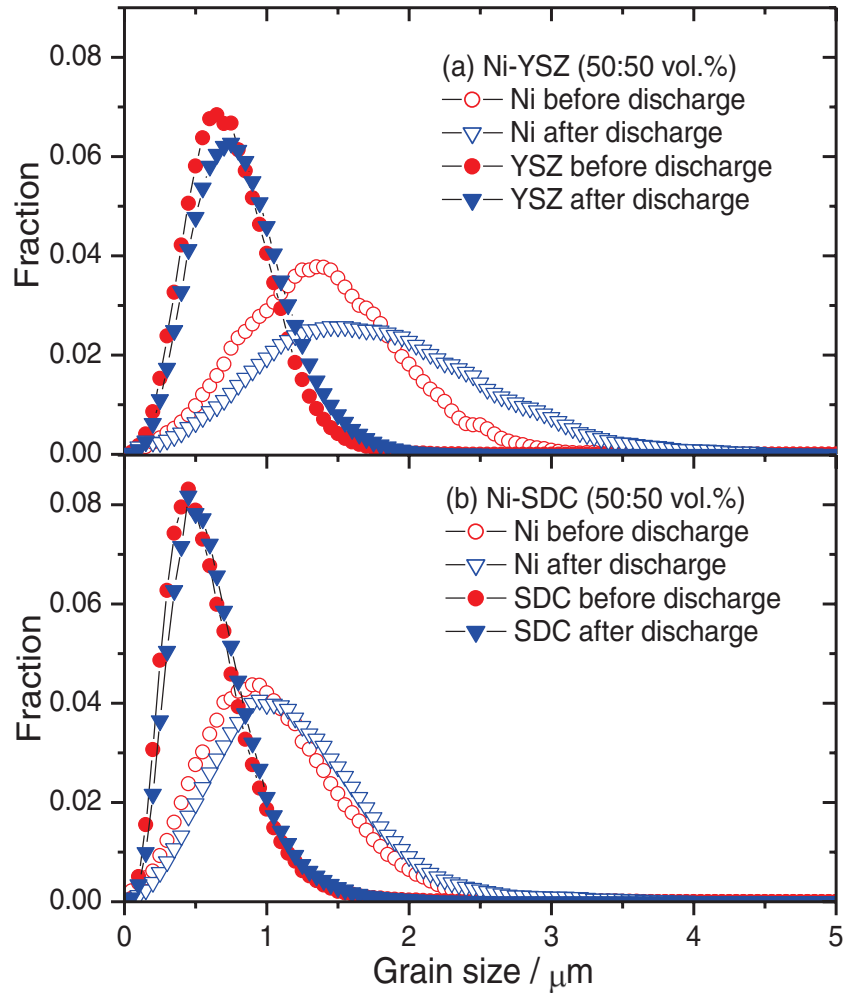

Figure 6. Distribution of grain sizes before and after discharge under $40 \%$ $\mathrm{H}_{2} \mathrm{O}-60 \% \mathrm{H}_{2}$; (a) Ni-YSZ and (b) Ni-SDC.

on the electrochemical reaction is well known, and some electrode kinetic models have been proposed for Ni-YSZ anodes $;{ }^{14-21}$ the role of interstitial hydrogen and hydroxyl formation at the Ni/YSZ interfaces, and the effects of surface reactions on YSZ surface. At this stage, however, every mechanism has not achieved the sufficient consensus to step up the detailed discussion in this study. Above the steam concentration of $25 \%$, the interfacial conductivity decreased probably due to the inhibition of dissociative adsorption of hydrogen by the excess amount of steam. In contrast, the interfacial conductivity of the Ni-SDC anode showed an almost linear relation against the logarithm of $P\left(\mathrm{O}_{2}\right)$ and $P\left(\mathrm{H}_{2} \mathrm{O}\right)$ despite the low electrocatalytic activity. This peculiar behavior indicated a high affinity for steam and will be strongly associated with the bulk properties and surface catalytic activity of SDC as described above. Thus, the affinity for steam will be the important index to predict the stability of anodes and define the operating condition.

Hereafter, the microstructural changes in Ni-YSZ and Ni-SDC anodes upon discharge under a highly humidified atmosphere in Fig. 2 were quantified and compared to clarify the impact on electrochemical behavior. Sample dimension of 3D reconstructed anodes and volume fraction in each phase are summarized in Table I. The volume ratio of $\mathrm{Ni}$ to oxide in each sample was almost unity, which is comparable

\begin{tabular}{|c|c|c|c|c|}
\hline \multirow[b]{3}{*}{ Treatment } & \multicolumn{4}{|c|}{$\begin{array}{l}\text { Average grain size of each component } \\
\text { in cermet anode }\end{array}$} \\
\hline & \multicolumn{2}{|c|}{$\mathrm{Ni}-\mathrm{SDC}$} & \multicolumn{2}{|c|}{$\mathrm{Ni}-\mathrm{YSZ}$} \\
\hline & $\mathrm{Ni}$ & SDC & $\mathrm{Ni}$ & YSZ \\
\hline Before discharge & $1.08 \mu \mathrm{m}$ & $0.62 \mu \mathrm{m}$ & $1.38 \mu \mathrm{m}$ & $0.73 \mu \mathrm{m}$ \\
\hline After discharge & $1.22 \mu \mathrm{m}$ & $0.66 \mu \mathrm{m}$ & $1.75 \mu \mathrm{m}$ & $0.80 \mu \mathrm{m}$ \\
\hline
\end{tabular}

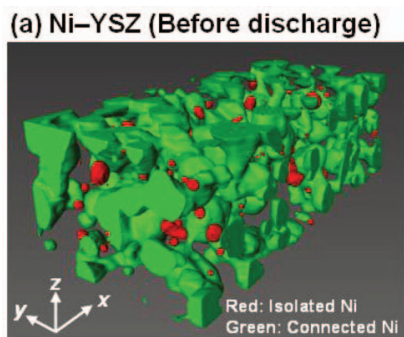

(c) Ni-SDC (Before discharge)

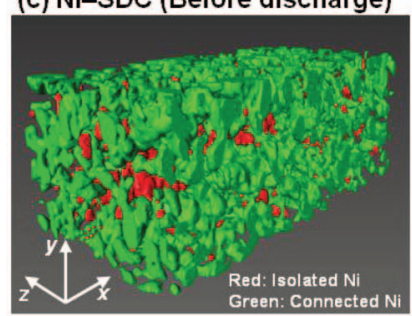

\section{(b) Ni-YSZ (After discharge)}

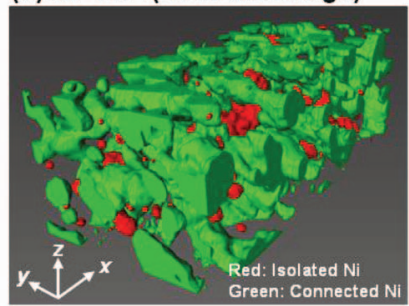

(d) Ni-SDC (After discharge)

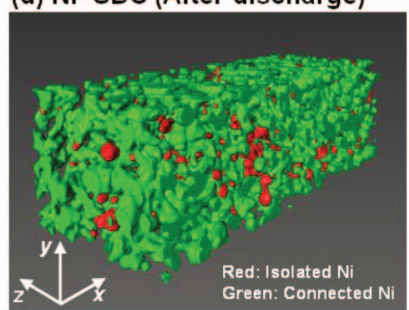

Figure 7. 3D reconstructed Ni phase for each anode, $(\mathrm{a}, \mathrm{b}) \mathrm{Ni}-\mathrm{YSZ}$ and (c, d) Ni-SDC.

to the nominal mixing ratio of powders in the sample preparation. Figure 6 displays the grain size distribution of $\mathrm{Ni}$ and oxide particles in $\mathrm{Ni}$-oxide anodes before and after discharge, and the average grain size in each phase is listed in Table II. Before discharge the average grain size of each component was different, which resulted from the differences in the sizes and sintering performances of the raw materials and the firing temperature of the anode slurries on YSZ disk. In both anodes, the oxide components maintained the rigid framework throughout the discharge tests in Fig. 2. Note that a significant growth in the grain size of Ni proceeded for the cell with $\mathrm{Ni}-\mathrm{YSZ}$ anode which may well correspond to abrupt degradation of the cell performance. On the other hand, the size change observed in Ni-SDC anode was quite small. The isolated phase ratio and volume specific TPB length for 3D reconstructed $\mathrm{Ni}$-oxide cermet anodes before and after discharge are summarized in Table III. The images of 3D reconstructed Ni phase for each anode are also displayed in Fig. 7; green and red regions correspond to connected and isolated $\mathrm{Ni}$ phases, respectively. In this evaluation, the isolated phase is geometrically defined as the "phase"

Table I. Sample dimension of 3D reconstructed anodes and volume fraction in each phase.

\begin{tabular}{|c|c|c|c|c|c|c|c|}
\hline & & \multicolumn{3}{|c|}{ Sample dimension / $\mu \mathrm{m}$} & \multicolumn{3}{|c|}{ Volume fraction $/ \%$} \\
\hline & & $x$ & $y$ & $z$ & $\mathrm{Ni}$ & Oxide & Pore \\
\hline $\mathrm{Ni}-\mathrm{SDC}$ & Before discharge & 30.53 & 12.36 & 15.62 & 21.4 & 22.4 & 56.2 \\
\hline & After discharge & 37.64 & 12.05 & 14.65 & 23.6 & 24.3 & 52.1 \\
\hline $\mathrm{Ni}-\mathrm{YSZ}^{\mathrm{a}}$ & $\begin{array}{l}\text { Before discharge } \\
\text { After discharge }\end{array}$ & $\begin{array}{l}25.77 \\
27.63\end{array}$ & $\begin{array}{c}11.62 \\
9.38\end{array}$ & $\begin{array}{c}6.57 \\
13.00\end{array}$ & $\begin{array}{l}25.3 \\
23.6\end{array}$ & $\begin{array}{l}25.1 \\
25.4\end{array}$ & $\begin{array}{l}49.6 \\
51.0\end{array}$ \\
\hline
\end{tabular}

\footnotetext{
a The data sets of Ni-YSZ before and after discharge were referred from Refs. 10 and 8, respectively.
} 
Table III. Isolated phase ratio and volume specific TPB length in Ni-SDC and Ni-YSZ anodes.

\begin{tabular}{|c|c|c|c|c|c|c|}
\hline & & \multicolumn{3}{|c|}{ Isolated phase ratio $/ \%$} & \multicolumn{2}{|c|}{ TPB length $/ \mu \mathrm{m} \mu \mathrm{m}^{-3}$} \\
\hline \multicolumn{2}{|c|}{ Anode $(\mathrm{Ni}:$ Oxide $=50: 50 \mathrm{vol} \%)$} & $\mathrm{Ni}$ & Oxide & Pore & Total & Active $^{*}$ \\
\hline \multirow[t]{2}{*}{$\mathrm{Ni}-\mathrm{SDC}$} & Before discharge & 10.9 & 3.5 & 0.0 & 3.07 & 2.16 \\
\hline & After discharge & 12.6 & 1.4 & 0.0 & 2.77 & 2.02 \\
\hline \multirow[t]{2}{*}{$\mathrm{Ni}-\mathrm{YSZ}$} & Before discharge & 3.8 & 2.3 & 0.0 & 2.49 & 2.02 \\
\hline & After discharge & 10.1 & 0.3 & 0.0 & 1.68 & 1.28 \\
\hline
\end{tabular}

*Active TPB length was geometrically defined.

which is unconnected to the any outer faces of the reconstructed rectangular block in the figure. Thus, the isolated phase is inactive for the electrochemical reaction when the constituent materials are pure ionic or electronic conductors. In response to this geometric definition, the active TPB length was calculated by subtracting the inactive TPBs connected to the isolated phase. However, this classification is inapplicable for the cermet anodes with mixed conductors such as ceria-based oxides. In the case of Ni-SDC anode, the geometrically isolated $\mathrm{Ni}$ phase can serve as the electron conduction path due to the mixed conduction in SDC phase, leading to an increment in the reactive sites. In other words, the TPBs ascribed to the isolated phase are not completely inactive. Note that the electrochemical activity in such sites is expected to be inferior to that in active TPBs because even under strongly reducing atmospheres the electronic conductivity of SDC is more than 4 orders of magnitude lower than that of nickel metal at $1000^{\circ} \mathrm{C}^{22-24}$ For Ni-YSZ anode, the proportion of the isolated $\mathrm{Ni}$ phase increased from ca. $4 \%$ to ca. $10 \%$ after deterioration while those in YSZ and pore phases were almost unchanged. This result indicates the destruction of electronic conduction path due to the agglomeration of nickel as observed in Fig. 6. On the other hand, the increase of the isolated $\mathrm{Ni}$ phase in $\mathrm{Ni}-\mathrm{SDC}$ anode was only ca. $2 \%$ upon discharge. The relatively large proportion of $10.9 \%$ in the initial $\mathrm{Ni}$ phase will be related to small average grain sizes of constituent materials. The TPB length in Ni-SDC anode was larger than that in $\mathrm{Ni}-\mathrm{YSZ}$ anode both before and after discharge operation; the electrochemically active sites were widespread in Ni-SDC anode. Thus, $\mathrm{Ni}-\mathrm{SDC}$ anode possesses a suitable microstructure from the geometric aspect as well as the inherent chemical properties of SDC in reducing atmospheres as presented above. The difference in the reduction rate of TPB length upon discharge was noticeable between two cermet anodes; ca. $7 \%$ and ca. 37\% reduction in geometrically active TPB length were confirmed for $\mathrm{Ni}-\mathrm{SDC}$ and $\mathrm{Ni}-\mathrm{YSZ}$, respectively. The local $P\left(\mathrm{H}_{2} \mathrm{O}\right)$ in the vicinity of active sites significantly affects the extent of microstructural change because the aggregation of nickel particles is accelerated by the presence of steam. During the galvanostatic operation, consequently, the load per active site determines the long term stability under highly humidified atmospheres.

\section{Conclusions}

The influence of the oxide component in Ni-oxide based cermet anodes on performance stability under a highly humidified atmosphere was studied. The cell with Ni-SDC anode showed no change in performance during discharge, whereas $\mathrm{Ni}$-zirconia based anodes were degraded with an increase in ohmic resistance. The performance stability appears to be determined by the difference in the local $P\left(\mathrm{H}_{2} \mathrm{O}\right)$ in the vicinity of the electrochemically active sites because the surface oxidation of nickel particles is the main degradation factor. In this respect, Ni-SDC anode had a superior mechanism to suppress the local increase of $P\left(\mathrm{H}_{2} \mathrm{O}\right)$ at around the active zone. This fact was confirmed by the suitable microstructure from the geometric aspect as well as the inherent chemical properties of SDC in reducing atmospheres. These findings provide the important design guide to establish the robust SOFCs.

\section{Acknowledgments}

This work was supported by the New Energy and Industrial Technology Development Organization (NEDO), Japan (Development of System and Elemental Technology on Solid Oxide Fuel Cell Project). The authors express thanks to Masashi Kishimoto, Daisuke Hayashi, and Professor Hiroshi Iwai, Department of Aeronautics and Astronautics, Kyoto University, for the evaluation of the TPB length by the volume expansion method.

\section{References}

1. H. Yokokawa, ECS Transactions, 35(1), 207 (2011).

2. T. Matsui, J.-Y. Kim, H. Muroyama, M. Shimazu, T. Abe, M. Miyao, and K. Eguchi, Solid State Ionics, in press.

3. A. Gubner, H. Landes, J. Metzger, H. Seeg, and R. Stúbner, in Proceedings of theFifth International Symposium on Solid Oxide Fuel Cells (SOFC-V), U. Stimming, S. C. Singhal, H. Tagawa, and W. Lehnert, Editors, PV 97-40, p. 884, The Electrochemical Society Proceedings Series, Pennington, NJ (1997).

4. M. Cassidy, G. Lindsay, and K. Kendall, J. Power Sources, 61, 189 (1996).

5. R. J. Aaberg, R. Tunold, M. Mogensen, R. W. Berg, and R. Ødegård, J. Electrochem. Soc., 145, 2244 (1998).

6. S. P. Jiang, J. Mater. Sci., 38, 3775 (2003).

7. S. Koch, P. V. Hendriksen, M. Mogensen, Y.-L. Liu, N. Dekker, B. Rietveld, B. de Haart, and F. Tietz, Fuel Cells, 6, 130 (2006).

8. T. Matsui, R. Kishida, J.-Y. Kim, H. Muroyama, and K. Eguchi, J. Electrochem. Soc., 157, B776 (2010)

9. T. Matsui, M. Inaba, A. Mineshige, and Z. Ogumi, Solid State Ionics, 176, 647 (2005).

10. H. Iwai, N. Shikazono, T. Matsui, H. Teshima, M. Kishimoto, R. Kishida, D. Hayashi, K. Matsuzaki, D. Kanno, M. Saito, H. Muroyama, K. Eguchi, N. Kasagi, and H. Yoshida, J. Power Sources, 195, 955 (2009).

11. T. Horita, H. Kishimoto, K. Yamaji, Y. Xiong, N. Sakai, M. E. Brito, and H. Yokokawa, Solid State Ionics, 177, 1941 (2006).

12. M. Watanabe, H. Uchida, and M. Yoshida, J. Electrochem. Soc., 144, 1739 (1997).

13. T. Matsui, H. Fujii, A. Ozaki, T. Takeuchi, R. Kikuchi, and K. Eguchi, J. Electrochem. Soc., 154, B1237 (2007).

14. C. Sun and U. Stimming, J. Power Sources, 171, 247 (2007).

15. M. Mogensen and S. Skaarup, Solid State Ionics, 86-88, 1151 (1996)

16. P. Holtappels, L. G. J. De Haart, and U. Stimming, J. Electrochem. Soc., 146, 1620 (1999).

17. P. Holtappels, I. C. Vinke, L. G. J. De Haart, and U. Stimming, J. Electrochem. Soc., 146, 2976 (1999).

18. S. P. Jiang and S. P. S. Badwal, J. Electrochem. Soc., 144, 3777 (1997).

19. S. P. Jiang and S. P. S. Badwal, Solid State Ionics, 123, 209 (1999).

20. N. Sakai, K. Yamaji, Y. P. Xiong, H. Kishimoto, T. Horita, and H. Yokokawa, J. Electroceramics, 13, 677 (2004).

21. J. Mizusaki, H. Tagawa, T. Saito, K. Kamitani, T. Yamamura, K. Hirano, S. Ehara, T. Takagi, T. Hikita, M. Ipponmatsu, S. Nakagawa, and K. Hashimoto, J. Electrochem. Soc., 141, 2129 (1994)

22. U. Anselmi-Tamburini, G. Chiodelli, M. Arimondi, F. Maglia, G. Spinolo, and Z. A. Munir, Solid State Ionics, 110, 35 (1998).

23. H. Yahiro, Y. Eguchi, K. Eguchi, and H. Arai, J. Appl. Electrochem., 18, 527 (1988).

24. I. Yasuda, The 24th Symposium on Solid State Ionics in Japan, Extended Abstracts, 147-148 (1998). 